\title{
Sistem Pakar Diagnosa Kerusakan Dan Perawatan Laptop
}

\author{
Muhammad Sadly¹, Ahmad Ali Hakam Dani², Hisma Abduh ${ }^{3}$ \\ 1,2,3 Universitas Andi Djemma Palopo, Palopo \\ sadlyam74@gmail.com, ahmad.ali.hd90@gmail.com, isma.syakirah21@gmail.com
}

\begin{abstract}
Expert System for diagnosing laptop damage and maintenance is an information and communication system that arises to provide solutions to a problem related to the laptop itself. This system is designed using the backward chaining method with the first dept technique as its inference engine, black box as a testing system, Microsoft access 2007 as the database and visual basic 6.0 as the programming language. Data collection was carried out for three months using interview and observation methods which were located at Central Media Computer. This research resulted in an expert system to provide information on symptoms, diagnoses and solutions to laptop damage and in the usability aspect based on testing using the Computer System Usability Questionnare produced a total score of 1538 which was converted on an index scale to a value of $85.4 \%$ included in the "Very Eligible" category.
\end{abstract}

Keywords: Expert System, Backward Chaining, Laptop Damage Diagnosis, Visual Basic.

\section{Abstrak}

Sistem pakar diagnosa kerusakan dan perawatan laptop merupakan sistem informasi dan komunikasi yang timbul untuk memberikan solusi dari suatu permasalahan terkait laptop itu sendiri. Sistem ini dirancang menggunakan metode backward chaining dengan teknik dept first sebagai mesin inferensinya, black box sebagai pengujian sistemnya, Microsoft Access 2007 sebagai basis datanya dan Visual Basic 6.0 sebagai bahasa pemogramannya. Pengumpulan data dilakukan selama tiga bulan dengan metode wawancara dan observasi yang bertempat di Central Media Computer. Penelitian ini menghasilkan sistem pakar untuk memberikan informasi gejala, diagnosa dan solusi atas kerusakan laptop dan pada aspek usability berdasarkan pengujian menggunakan Computer System Usability Questionnare menghasilkan skor total sebesar 1538 yang dikonversikan dalam skala index mendapatkan nilai sebesar 85,4\% masuk dalam kategori "Sangat Layak".

Kata Kunci: Sistem Pakar, Backward Chaining, Diagnosa Kerusakan Laptop, Visual Basic.

\section{PENDAHULUAN}

Teknologi sistem informasi dan komunikasi pada masa ini, sangatlah berkembang pesat, baik dari segi manfaatnya maupun penggunaannya secara umum, terutama sistem aplikasi atau program pada komputer. Berbagai macam aktifitas dari manusia dapat dengan mudah dikerjakan oleh sistem aplikasi komputer, yang sebelumnya dalam aktifitas manusia hanya dapat dikerjakan oleh manusia tersebut [1]. Kedudukan teknologi atau sistem aplikasi pada komputer dalam kehidupan manusia kini sulit untuk dipisahkan, dikarenakan peran dan fungsinya terhadap manusia. Sistem pakar merupakan suatu sistem informasi dan komunikasi yang timbul untuk memberikan solusi dari suatu permasalahan tertentu [2].

Sistem pakar diciptakan tidak untuk menggantikan kedudukan seorang pakar tetapi untuk memasyarakatkan pengetahuan dan pengalaman pakar tersebut. Sistem pakar mempunyai keuntungan dibandingkan dengan seorang 
pakar yaitu kepakarannya dapat dimanfaatkan oleh masyarakat tanpa kehadiran sang pakar, lebih menghemat waktu dan biaya serta lebih mudah dalam penggunaannya. Maka dengan kehadiran sistem pakar ini diharapkan dapat lebih mempermudah mengidentifikasi suatu permasalahan dan mendapatkan suatu solusi yang nyata [3]. Para pengguna laptop tidak sedikit juga menemukan permasalahan yang membuat dirinya harus berurusan dengan para pakar atau teknisi laptop.

Troubleshooting laptop dengan sistem pakar memungkinkan siapa saja yang sedang mempunyai permasalahan dengan perangkat keras (hardware) maupun perangkat lunak (software) untuk mendeteksi kerusakan dan mengambil tindakan atas permasalahan yang dihadapi [4]. Dengan demikian, jika pengguna tidak mampu atau tidak dapat memperbaiki kerusakan laptopnya dengan panduan sistem pakar ini, maka sistem pakar tetap mempunyai pengaruh, seminimal mungkin menambah ilmu troubleshooting kepada para pengguna laptop. Disamping itu, jika situasi mengharuskan laptop untuk diserahkan kepada teknisi laptop, dengan adanya sistem pakar juga dapat membantu meringankan tugas seorang teknisi laptop dalam mengidentifikasi suatu permasalahan yang dihadapi.

Sehubungan dengan latar belakang seperti yang diuraikan sebelumnya, maka penulis merumuskan permasalahan dalam penelitian yaitu bagaimana membangun suatu sistem pakar yang berguna sebagai alat bantu untuk mendiagnosa kerusakan dan perawatan laptop ?. Sistem pakar diagnosa kerusakan dan perawatan laptop ini dibangun menggunakan program (Basis) Visual Basic versi 6.0,Microsoft Acces 2007 sebagai Data Base dan mencakup permasalahan Hardware dan Software laptop secara umum.Mesin inferensi yang digunakan dalam pembuatan sistem pakar ini yaitu backward chaining. Berdasarkan rumusan masalah yang ada, maka tujuan dari penelitian ini yaitu mengetahui cara membangun sistem pakar diagnose kerusakan dan perawatan laptop.Adapun manfaat dari penelitian ini memberikan kemudahan kepada para pengguna laptop mengetahui kerusakan maupun seorang teknisi, sehingga dapat menemukan solusi lebih cepat pada kerusakan laptop.

\section{METODOLOGI PENELITIAN}

\subsection{Sistem Pakar}

Sistem pakar adalah salah satu cabang dari Artificial Intelligence (AI) dan juga merupakan bidang ilmu yang muncul seiring perkembangan ilmu computer saat ini [5]. Seorang pakar dengan sistem pakar mempunyai banyak perbedaan. Darkin (1994) mengemukakan perbandingan kemampuan antara seorang pakar dengan sebuah sistem pakar seperti pada Tabel 1 [6].

Tabel 1. Perbandingan kemampuan seorang pakar dengan sistem pakar

\begin{tabular}{|l|l|l|}
\hline \multicolumn{1}{|c|}{ Factor } & \multicolumn{1}{c|}{ Human Expert } & Expert system \\
\hline Time availability & Hari kerja & Setiap saat \\
\hline Geografis & Lokal/tertentu & Di mana saja \\
\hline Keamanan & Tidak tergantikan & Dapat diganti \\
\hline Perishable/dapat habis & Ya & Tidak \\
\hline
\end{tabular}

Sistem Pakar Diagnosa Kerusakan Dan Perawatan Laptop (Muhammad Sadly) |283 
Jurnal Riset Sistem Informasi Dan Teknik Informatika (JURASIK)

Volume 5 Nomor 2 Agustus, pp 282-288

ISSN: 2527-5771/EISSN: 2549-7839

https://tunasbangsa.ac.id/ejurnal/index.php/jurasik

\begin{tabular}{|l|l|l|}
\hline \multicolumn{1}{|c|}{ Factor } & Human Expert & Expert system \\
\hline Performansi & Variable & Konsisten \\
\hline Kecepatan & Variable & Konsisten \\
\hline Biaya & Tinggi & Terjangkau \\
\hline
\end{tabular}

\subsection{Backward Chaining}

Terdapat dua pendekatan untuk mengontrol inferensi dalam sistem pakar berbasis aturan, yaitu pelacakan ke belakang (backward chaining) dan pelacakan ke depan (forward chaining) [7]. Pelacakan ke belakang adalah pendekatan yang dimotori tujuan (goal-driven). Dalam pendekatan ini pelacakan dimulai dari tujuan, selanjutnya dicari aturan yang memiliki tujuan tersebut untuk kesimpulannya. Selanjutnya proses pelacakan menggunakan premis untuk aturan tersebut sebagai tujuan baru dan mencari aturan lain dengan tujuan baru sebagai kesimpulannya [8]. Adapun karakteristik dari backward chaining sebagai berikut :
a) Diagnosis
b) Disajikan untuk masa lalu
c) Konsekuen ke antecedent
d) Tujuan memandu, penalaran dari atas kebawah
e) Bekerja kebelakang untuk mendapatkan fakta yang mendukung hipotesis
f) Dept First search dimudahkan
g) Konsekuen menentukan pencarian
h) Penjelasan difasilitasi

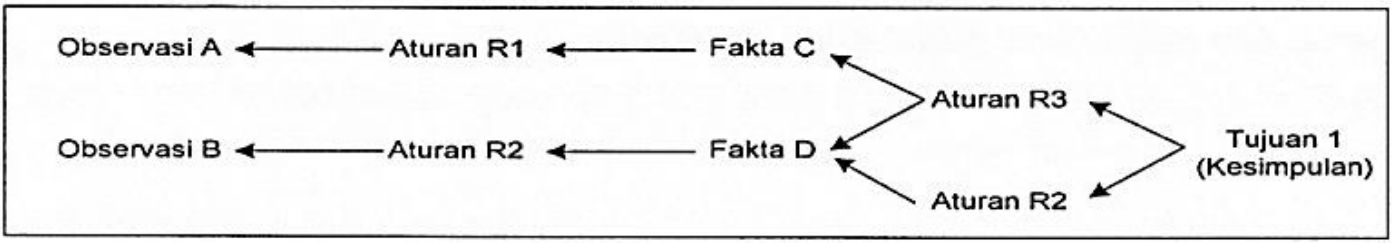

Gambar 1. Proses backward chaining

\subsection{Visual Basic 6.0}

Bahasa basic pada dasarnya adalah bahasa yang mudah dimengerti sehingga pemrograman di dalam bahasa Basic dapat dengan mudah dilakukan meskipun oleh orang yang baru belajar membuat program. Hal ini lebih mudah lagi setelah hadirnya Microsoft Visual Basic, yang dibangun dari ide untuk membuat bahasa yang sederhana dan mudah dalam pembuatan scriptnya (simple scripting language) untuk graphic user interface yang dikembangkan dalam sistem operasi Microsoft Windows [3]. 
Jurnal Riset Sistem Informasi Dan Teknik Informatika (JURASIK)

Volume 5 Nomor 2 Agustus, pp 282-288

ISSN: 2527-5771/EISSN: 2549-7839

https://tunasbangsa.ac.id/ejurnal/index.php/jurasik

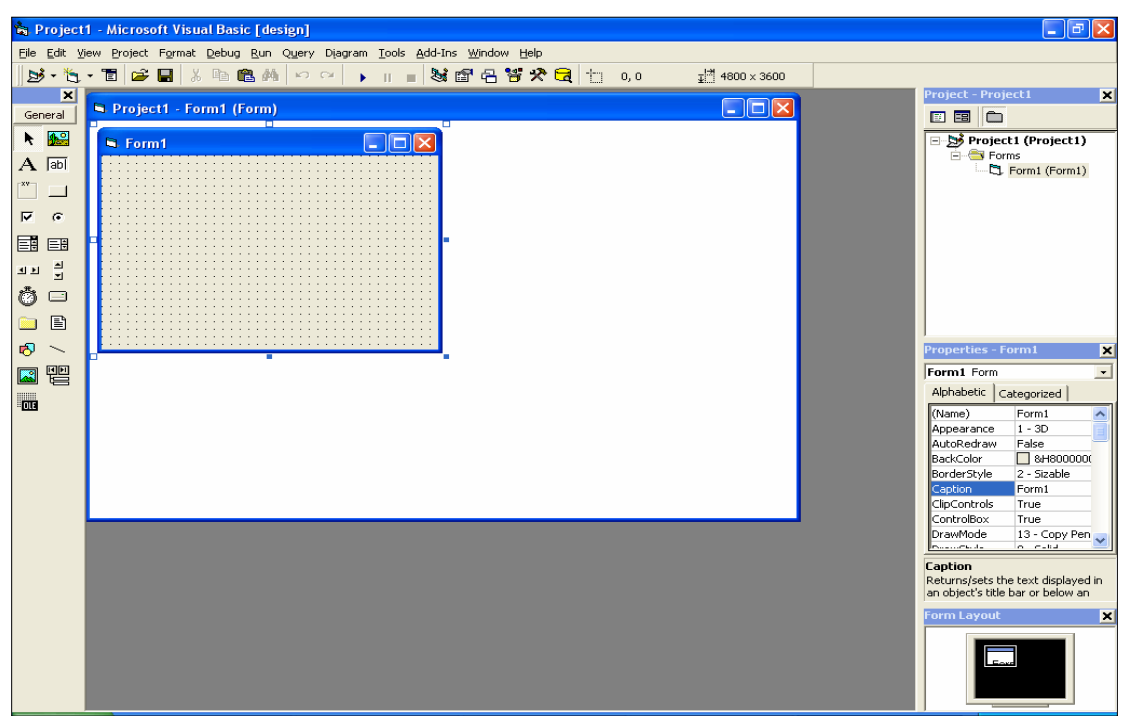

Gambar 2. Interface antar muka visual basic 6.0

Penelitian ini menggunakan metode penelitian kualitatif sebagai prosedur penelitian yang menghasilkan data deskriptif berupa kata-kata tertulis lisan dari orang-orang dan perilaku yang dapat diamati [4]. Adapun alur penelitian pada Gambar 3. Terdapat beberapa langkah seperti pemilihan macam, jenis dan ciri kerusakan yang diidentifikasi, kemudian diteruskan pada segment proses penghasil solusi yang terdapat pada data base sebagai penyimpanan basis pengetahuan sistem pakar diagnosa kerusakan dan perawatan laptop.

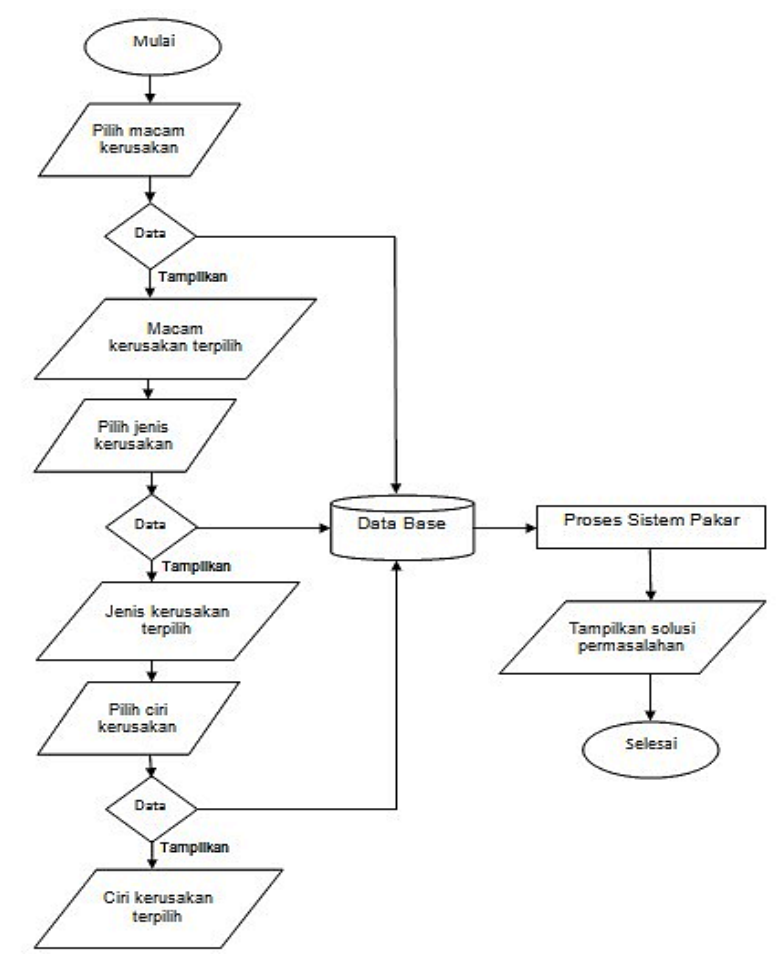

Gambar 3. Alur penelitian 
Metode peneltian yang digunakan yaitu metodewaterfall yang merupakan sebuah metode dalam pengembangan sistem secara berurutan dan dilakukan untuk membuat pembaruan sistem yang berjalan.

\section{HASIL DAN PEMBAHASAN}

\subsection{Use Case Diagram}

Use case diagram untuk sistem pakar kerusakan dan perawatan laptop dapat dilihat pada Gambar 4.

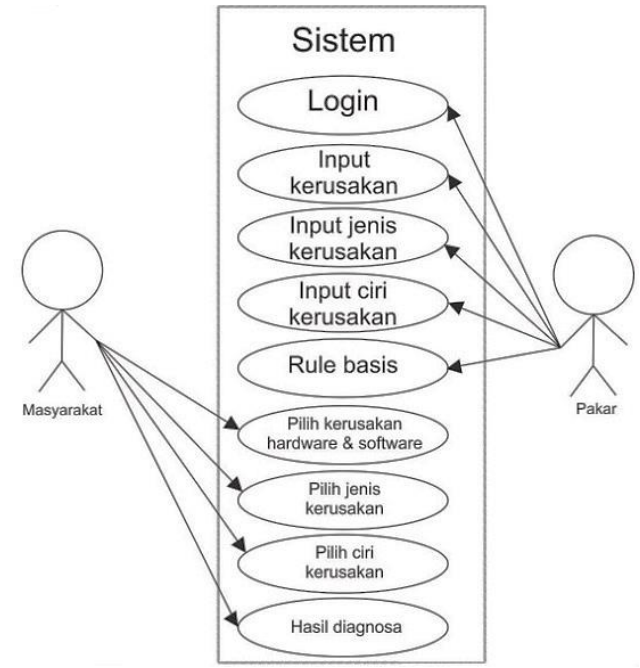

Gambar 4. Use case diagram

Pada diagram use case yang diusulkan admin dapat login, dapat mengelola dan memasukkan basic data macam kerusakan, mengelola dan memasukkan basic data jenis kerusakan, mengelola dan memasukkan basic data ciri kerusakan dan mengelola basic aturan. Sedangkan pemakai dapat melakukan analisis dan dapat mendapatkan hasil diagnosa kerusakanlaptop.

\subsection{Relasi Tabel}

Pada Gambar 5 ini merupakanrelasi antar tabel pada sistem pakar diagnosa kerusakan dan perawatan laptop.

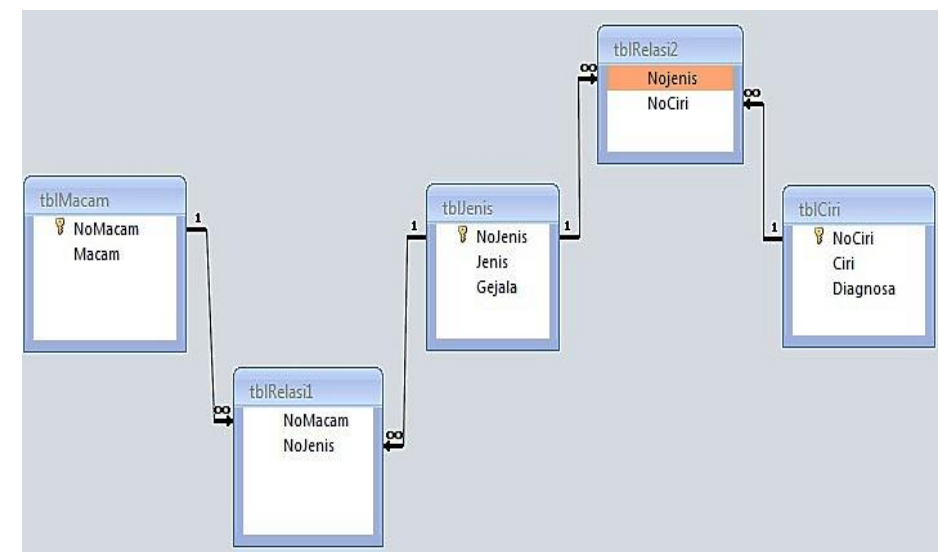

Gambar 5. Relasi tabel 


\subsection{Rancangan Rule}

Sebelum memulai perancangan rule, perlu diketahui tabel dentifikasi masalah terlebih dahulu. Adapun identifikasi masalah adalah mencari berbagai permasalahan laptop pada tempat penelitian. Permasalahan yang diidentifikasi pada Toko Central Media Computer adalah dari segi Hardware dan Software. Setelah masalah teridentifikasi, kemudian penentuan atau perancangan rule itu sendiri. Dari beberapa kerusakan yang telah diinputkan, telah disusun rule berdasarkan buku dan hasil konsultasi dengan pakar, dalam hal ini adalah teknisi. Rule yang disusun adalah rule yang tidak bertingkat. Rule yang tidak bertingkat itu sendiri merupakan kerusakan yang belum ada kerusakan lain yang memiliki gejala umum yang serupa dalam data base.

Tabel 2. Identifikasi masalah

\begin{tabular}{|c|c|c|c|c|c|}
\hline No & $\begin{array}{c}\text { Macam } \\
\text { Kerusakan }\end{array}$ & $\begin{array}{c}\text { Kode } \\
\text { Kerusakan }\end{array}$ & $\begin{array}{c}\text { Jenis } \\
\text { Kerusakan }\end{array}$ & $\begin{array}{l}\text { Kode } \\
\text { Gejala }\end{array}$ & Gejala \\
\hline \multirow[t]{12}{*}{1} & Hardware & K01 & Keyboard & G01 & Semua tombol tidak berfungsi \\
\hline & \multirow[t]{11}{*}{ Hardware } & & & G02 & $\begin{array}{l}\text { Hanya satu atau beberapa tombol yang } \\
\text { tidak berfungsi }\end{array}$ \\
\hline & & K02 & Layar & G03 & Layar monitor bergaris ketika $O N$ \\
\hline & & & & G04 & Layar redup ketika $O N$ \\
\hline & & K03 & Speaker & G05 & Speaker tidak mengeluarkan bunyi \\
\hline & & & & G06 & Bunyi yang dikeluarkan pecah \\
\hline & & K04 & Touchpad & G07 & Pointer tidak bergerak \\
\hline & & K05 & USB Port & G08 & Tidak berfungsi \\
\hline & & K06 & HDMI Port & G09 & Tidak berfungsi \\
\hline & & K07 & Audio Port & G10 & Tidak berfungsi \\
\hline & & K08 & Kipas & G11 & Panas berlebih (Overheat) \\
\hline & & K09 & Hardisk & G12 & $\begin{array}{l}\text { Muncul pesan not responding pada } \\
\text { tampilan windows }\end{array}$ \\
\hline \multirow[t]{8}{*}{2} & \multirow[t]{8}{*}{ Hardware } & K10 & Baterai & G13 & Cepat lowbat atau tidak mengisi \\
\hline & & K11 & CMOS & G14 & $\begin{array}{l}\text { Waktu dan tanggal pada windows } \\
\text { berubah-ubah }\end{array}$ \\
\hline & & K12 & Mainboard & G15 & Mati total \\
\hline & & K13 & Wifi & G16 & Tidak dapat mendeteksi jaringan \\
\hline & & K14 & DVD ROM & G17 & Disc tidak bisa terbaca \\
\hline & & K15 & Changer & G18 & $\begin{array}{l}\text { Lampu indicator pada adaptor menyala } \\
\text { dan tidak mengisi }\end{array}$ \\
\hline & & & & G19 & $\begin{array}{l}\text { Lampu indicator pada adaptor tidak } \\
\text { menyala dan tidak mengisi }\end{array}$ \\
\hline & & K16 & $\begin{array}{l}\text { Card } \\
\text { Reader }\end{array}$ & G20 & Tidak dapat membaca SD card \\
\hline \multirow[t]{3}{*}{3} & \multirow[t]{3}{*}{ Software } & K17 & Virus & G21 & $\begin{array}{l}\text { Terinstal aplikasi-aplikasi yang tidak } \\
\text { diinginkan ketika terhubung internet }\end{array}$ \\
\hline & & K18 & Windows & G22 & $\begin{array}{l}\text { Proses berjalannya aplikasi atau system } \\
\text { lambat }\end{array}$ \\
\hline & & & & G23 & Laptop tidak bias login \\
\hline
\end{tabular}

Tabel 3. Rancangan rule

\begin{tabular}{|c|l|l|l|l|}
\hline No & Rule & \multicolumn{1}{|c|}{ If } & And & Then \\
\hline 1 & R1 & G01 & G02 & K01 \\
\hline
\end{tabular}


Jurnal Riset Sistem Informasi Dan Teknik Informatika (JURASIK)

Volume 5 Nomor 2 Agustus, pp 282-288

ISSN: 2527-5771/EISSN: 2549-7839

https://tunasbangsa.ac.id/ejurnal/index.php/jurasik

\begin{tabular}{|c|l|l|l|l|}
\hline No & Rule & \multicolumn{1}{|c|}{ If } & And & Then \\
\hline 2 & R2 & G03 & G04 & K02 \\
\hline 3 & R3 & G05 & G06 & K03 \\
\hline 4 & R4 & G07 & - & K04 \\
\hline 5 & R5 & G08 & - & K05 \\
\hline 6 & R6 & G09 & - & K06 \\
\hline 7 & R7 & G10 & - & K07 \\
\hline 8 & R8 & G11 & - & K08 \\
\hline 9 & R9 & G12 & - & K09 \\
\hline 10 & R10 & G13 & - & K10 \\
\hline 11 & R11 & G14 & - & K11 \\
\hline 12 & R12 & G15 & - & K12 \\
\hline 13 & R13 & G16 & - & K13 \\
\hline 14 & R14 & G17 & - & K14 \\
\hline 15 & R15 & G18 & G19 & K15 \\
\hline 16 & R16 & G20 & - & K16 \\
\hline 17 & R17 & G21 & - & K17 \\
\hline 18 & R18 & G22 & G23 & K18 \\
\hline
\end{tabular}

\section{SIMPULAN}

Dalam membangun sistem pakar diagnosa kerusakan dan perawatan laptop diawali dengan perancangan sistem. Perancangan pada sistem ini menggunakan UML. Aplikasi sistem pakar diagnosa kerusakan dan perawatan laptop ini dibangun menggunakan bahasa pemrograman visual basic, dengan menggunakan metode waterfall dan pengujian aplikasinya menggunakan pengujian black box.

Berdasarkan kualitas perangkat lunak pada aspek usability menghasilkan skor total 1538 yang jika dikonversikan ke dalam skala index mendapatkan nilai sebesar 85,4\%. Skala kualitatif masuk dalam kategori "Sangat Layak" dan memenuhi aspek usability. Sedangkan, berdasarkan pengujian instrumen data untuk aspek validitas dan reliabilitas dinyatakan valid dan reliable.

\section{DAFTAR PUSTAKA}

[1] Desiani Anita, Muhammad Arhami. Konsep Kecerdasan Buatan. Yogyakarta: ANDI, 2006.

[2] Arhami, Muhammad. Konsep Dasar Sistem Pakar. Yogyakarta: ANDI, 2005.

[3] Basuki, Achmad. Algoritma Pemograman 2 Menggunakan Visual Basic 6.0. Surabaya: ITS, 2006.

[4] Kurniawan, A. 2015. "13 Pengertian Analisis Menurut para Ahli di Dunia". (www.gurupendidikan.com/13-pengertian-analisa-menurut-para-ahlididunia).

[5] Saepulloh, A., Fatimah, D.D.S. 2016. "Pengembangan Sistem Pakar Diagnosa penyakit dan Hama Pada tanaman Padi Varietas Sarinah Berbasis Android". Jurnal ISSN : 2302-7339 Vol.13 No.1 2016. Garut : Sekolah Tinggi Teknologi Garut.

[6] Sudarsono. 2014. "Pengertian Bagan Alir (Flowchart)". (https://sudarsono.staff.gunadarma.ac.id/Download/files/16512/Flowchart.pdf).

[7] Suharto. "Pengendalian Hama Tanaman Padi ". Andi Offset. Yogyakarta.

[8] Sya'rudin, M. 2013. "Sistem Pakar Untuk Mendiagnosa Penyakit Pada Tanaman Jamur dengan Menggunakan Metode Backward Chaining". Surakarta : Universitas Muhammadyah Surakarta. 